\title{
ANTXR1 wt Allele
}

National Cancer Institute

\section{Source}

National Cancer Institute. ANTXR1 wt Allele. NCI Thesaurus. Code C104094.

Human ANTXR1 wild-type allele is located in the vicinity of 2p13.1 and is approximately $236 \mathrm{~kb}$ in length. This allele, which encodes anthrax toxin receptor 1 protein, is involved in the modulation of cytoskeletal rearrangement, cellular adhesion and cell migration. Mutation of the gene is associated with hemangioma capillary infantile. 